\title{
Airport Security, Terrorism and Mega EVENTS: HOW FAR CAN AND SHOULD WE GO?
}

Guilherme Damasceno

Pontifical Catholic University of Minas Gerais - PUCMG BRAZIL

$$
\approx
$$

\section{ABSTRACT}

The September 11th terrorist attacks reminded the world of something it appeared to have forgotten: the importance of commercial aviation as a terrorism target. There is no doubt that over the last 50 years commercial air travel has been a favorite target of terrorists, a fact that has made airports a key focus for anti-terrorism policies and measures. With Brazil hosting two of the world's largest sporting events - the football World Cup and the 2016 Olympic games - the eyes of the world are focused on the country's security preparations for such events. Perhaps for the first time, the organs responsible for public safety have to consider the subject of national level security seriously, and considerable challenges lie ahead. The recent mass street demonstrations, many of which ended in violence, tensions in the MiddleEast, economic crises and a lack of public confidence in government add to the risk factors to be considered. A potential increase in security measures at airports does not just represent a cost in terms of public finances, but also has implications in terms of greater restraints and limitations on individual liberties, which in turn may have a political price for the government. Finding a balance between costs, risks and possible benefits is one of the key challenges related to the choice of necessary, practical and suitable security measures for different social, economic and political contexts. The aim of the present article, which is based on a survey undertaken in an international airport, is to evaluate the level of tolerance of passengers in relation to stricter security procedures at Brazilian airports, especially during major events, as well as evaluating the perceived risk of a terrorist attack during the events. The intention is to show that, although the perceived risk of a terrorist attack among the public may be low, the great majority of passengers are in favor of increased airport security during such events. In doing so it is hoped that support may be provided for the difficult task of making decisions based on complex factors such as costs, risks and potential benefits.

KEYwORDS: Airport Security. Terrorism.Major events. Risk Perception. Cost-Benefit. Decision Making.

\section{INTRODUCTION}

Just as the terrorist's choice of his target is far from random, so the choice of airport security as the main subject of the research on which this 
article is based was not accidental. The desire of the terrorist is never simply the destruction of the immediate target itself, but rather fulfilment of the political objective that lies behind his actions (GIBBS, 1989). In this sense, the obsession that terrorists seem to have for planes and airports may appear surprising, especially considering that the same objectives have, especially since September $11^{\text {th }}$, been considered "hard targets" due to their high levels of security and consequently the greater difficulty that they represent in terms of the perpetrator carrying out a successful attack ${ }^{1}$. It is clear that shopping centers or theaters, for example, represent easier targets, with a greater chance of injuring large numbers of people.

In their book Aviation Terrorism and Security, written before the attack on the Twin Towers, the terrorism experts Brian Jenkins and Paul Wilkinson stated that "commercial aviation has been a favorite target of terrorists, who have viewed airlines as nationally-labeled containers of hostages in the case of hijackings, and victims in the case of sabotage". (JENKINS; WILKINSON, 1999, p4). Due to the importance of symbolism in the choice of targets for an attack, the plane has, in recent decades, become one of the terrorist's preferred objectives. Additionally, airline companies are frequently among the richest and most powerful companies in their respective countries. As such, when the terrorist attacks American Airlines, he is symbolically attacking the USA, politically, financially and culturally.

Furthermore, attacks involving aircraft result, on average, in the highest number of fatalities (ELIAS, 2010), which guarantees that the terrorist will achieve two of his additional typical aims: the attention of the media, often in a sensationalist manner, and the subsequent spread of fear. According to the author, attacks involving aircraft historically result in a higher proportion of deaths than any other type of terrorist attack².

It's even argued that what is today described as international terrorism began with the hijacking of an aircraft, when three armed men representing the PLO (the Palestine Liberation Organization) took control of a plane belonging to the Israeli airline $\mathrm{El} \mathrm{Al}$ on a commercial flight from Rome to Tel Aviv (HOFFMAN, 2006).

1 Further information relating to the concepts of hard targets and soft targets available at http://www. historyofwar.org/articles/concepts_terrortargets.html.

2 Even though the author's research refers specifically to american citizens, it seems safe to generalize the results.. 
In terms of Brazil, the theme of airport security and its relationship with terrorism tends to be underestimated by the authorities, and even by society in general, possibly as a result of the lack of terrorist attacks in the country's past ${ }^{3}$ or the absence, according to popular belief, of a local "par excellence" terrorist organizations. The aforementioned Paul Wilkinson (2007), while analyzing the history of attacks coordinated or at least inspired by the doctrines of $\mathrm{Al}$ Qaeda, considers it to be fatal error on the part of a country, even those where the majority of the population is Muslim, to consider itself immune to terrorist attack.

It is also worth highlighting, even considering the aforementioned premise, that the theory that Brazil does not have a history of terrorist attacks may be considered a half truth, especially in terms of commercial aviation. When the history of aircraft hijackings across the world is considered, it can be seen that at least 10 of these hijackings took place on Brazilian soil or involved aircraft flying under the Brazilian flag on their way to Brazil ${ }^{6}$. Furthermore, it is probable that the majority of Brazilians are unaware that following September $11^{\text {th }}$ several attacks against commercial aircraft have been registered involving the USA alone. (ZUCKERMAN; CARAFANO; BUCCI, 2012). It is important to highlight that airport security is

3 While it does not appear controversial to suggest that the majority of the Brazilian population does not consider the country to have a history of terrorist attacks, it is clear that such a categorical statement depends on what is understood as terrorism. For example, it is possible to argue that the State itself may commit acts of terrorism (State terrorism). In such case it is possible to identify a number of such terrorist acts in Brazil, committed during the dictatorship. There are those who argue, normally via blogs, that the left wing groups that fought against the dictatorship were also terrorists, as can be retrieved from http://wikiterrorismobrasil.blogspot.com.br/.

4 Obviously such a definition of terrorist attacks or a terrorist group depends, from the outset, on a definition of terrorism, a theme that has been debated at length across the world, both in political and academic circles, without a consensus being achieved. In the case of Brazil, in 2014 a law is likely to be passed defining the term. This proposed law has generated enormous controversy due to suspicions that its purpose is to prohibit or control more forceful street demonstrations.

5 The First Capital Command (Primeiro Comando da Capital - PCC) was inspired by the Red Command (Comando Vermelho). Both criminal organizations were formed by prisoners as selfprotection groups in Brazil's brutal prison system. The PCC arose in São Paulo in the 1990s, and has fought a bloody ongoing feud with police in the city. The group, now the largest and best-organized criminal organization in Brazil, is believed to have members in two-thirds of the country's states, and controls drug trafficking routes between Brazil, Bolivia, and Paraguay. More about PCC is available at http://www.insightcrime.org/groups-brazil/first-capital-command-pcc. In terms of groups such as the PCC, the general opinion is that such an organization is not a terrorist group, following the considerations of the security expert Marcus Reis, even though the group do commit acts of terrorism. His opinion can be retrieved from $<$ http://marcusreis.com/2013/09/12/pacto-terrorismo-e-crimeorganizado/>.

6 The website Aviation Safety Network provides an extensive database of aircraft hijackings, including those which took place in Brazil. Available at http://aviation-safety.net/database/. 
particularly challenging given that the terrorist is not so foolish as to use the same method for every attempt. (SCHNEIER, 2008). If the tendency today is aircraft hijacking, tomorrow it may be the planting of bombs in baggage compartments ("sabotage") or the downing the aircraft with more and more sophisticated MANPAD’s (man-portable air-defense systems) ${ }^{7}$.

In the opinion of a number of security analysts ${ }^{8}$, major events such as the football World Cup and the Olympic Games will put Brazil on the international terrorism map. The majority agree that "the problem isn't Brazil", but more the presence of delegations from countries that are traditional targets of terrorism?. It should be remembered that Germany was not the direct target of the terrorist attacks at the Munich Olympics, and as such, believing that Brazil will be luckier than Germany because of the simple fact that it is considered a peaceful, "neutral" country is possibly naive. Contrastingly, the same concerns were felt about the World Cup in South Africa four years ago, and that event passed off peacefully ${ }^{10}$.

International terrorism analysts are, at time of writing, beginning to arrive at the conclusion that Brazil is in fact a country at high risk of an attack, not just because of its hosting of these events, but also because of its economic importance, its growing role in global politics, and its enormous social inequality ${ }^{11}$. When the strong possibility of large-scale popular street demonstrations, possibly with moments of violence, is added to the mix, the result, in the eyes of the majority of experts, is a worrying scenario. According to leaked reports published by the brazilian media, it also seems to be the conclusion reached by ABIN - the brazilian inteligence agency - which has warned the brazilian president Dilma about terrorism during the World $\mathrm{Cup}^{12}$.

7 Man-portable air-defense systems (MANPADS or MPADS) are shoulder-launched surface-to-air missiles (SAMs). They are typically guided weapons and are a threat to low-flying aircraft, especially helicopters. Retrieved from http://en.wikipedia.org/wiki/Man-portable_air-defense_systems.

8 Available at http://www.worldcrunch.com/world-affairs/a-giant-hole-in-brazil-039-s-antiterrorism-policy-for-world-cup-olympics/soccer-sport-sao-paulo-police-olympic-games-nationalsecurity/c1s11365/\#.Uwyke-NdWSo.

9 Retrieved from http://www.portal2014.org.br/noticias/12144/PARLAMENTARES+QUEREM +LEI+ANTITERRORISMO+ANTES+DA+COPA+DO+MUNDO.html.

10 The report on the risk of terrorism at the South Africa World Cup can be seen at http://www.estadao. com.br/noticias/esportes,africa-do-sul-nega-ameaca-de-terrorismo-as-vesperas-da-copa,559089,0.htm.

11 See, e.g., supra note 7.

12 Retrieved from http://veja.abril.com.br/120314/the-threats-to-the-world-cup.html. 
This however does not seem to be the opinion of the Brazilian people, at least among those who frequent the country's airports. A survey carried out at Aeroporto Internacional Tancredo Neves, located in the greater metropolitan area of Belo Horizonte, in the state of Minas Gerais, found that the majority of passengers interviewed felt that the risk of a terrorist attack in Brazil was low or very low (the question was not, on this occasion, restricted to attacks involving commercial aviation). In other words the risk perception, a term that has begun to be more used and studied by security experts, of passengers and possibly of Brazilians in general, is low. It is interesting to note that the majority of young people aged between 18 and 30 had a different perception of risk, with more than $60 \%$ of this group believing the risk was medium or high. The reasons for this result are not easy to identify, as will be discussed below.

It is not unusual for the layman and experts to hold different opinions in terms of risk perception. The psychologist Clinton M. Jenkin (2006) warned, in an article entitled "Risk Perception and Terrorism: Applying the Psychometric Paradigm", based on the studies of Slovic (1987), of the inconsistencies that can arise as a result of basing security policies solely on evaluations of risk performed by specialists. Both argue that the risk perception of those whose physical safety the same measures are trying to protect is also important, as the concept of risk is psychological and subjective, and is a phenomenon constructed by society.

While the low perception of risk of a terrorist attack may lead to an expectation of low tolerance regarding increased security procedures during major events, the survey revealed a different result. Even passengers who believed the risk of a terrorist attack to be low were in favor of heightened security at airports during such events. This seemingly contradictory finding will be discussed in greater detail later in this article.

Decisions that involve security measures arouse considerable controversy and are rarely limited to solely technical factors. They are, above all, political decisions, requiring serious analysis and taking into account anticipated risks, costs and benefits. An analysis of costs - not just financial, but also social and political - is a central part of the decision making process, as is a focus on proportionality, or in other words, the idea that costs must be proportional to the risks and benefits. The task is complicated further by psychological phenomenon common to the area of security. For example, 
it is normal for the predictability of an event to be exaggerated after it has happened (hindsight bias or "I knew it all along"). As well as this, errors tend to generate more attention than correct decisions (JENKIN, 2006).

In his book Beyond Fear, the security consultant Bruce Schneier (2003) argued that, when security measures are being discussed, especially those aimed at combating terrorism, it is necessary to think of the process as a type of exchange, or trade-off. For Schneier, "Critical to any security decision is the notion of trade-offs, meaning the costs - in terms of money, convenience, comfort, freedoms, and so on - that inevitably attach themselves to any security system "(SCHNEIER, 2003, p.3). Historically, on almost every occasion that a new security measure or procedure is implemented, a negotiation, conscious or otherwise, takes place. The gains in security normally involve giving up or conceding part of something that many authors consider to be non-negotiable: individual rights or liberties (SCHNEIER, 2008). As such, when the decision is made to install cameras throughout a city, seeking to improve public safety, there are inevitably negative impacts in terms of privacy.

Laura Donohue (2008), in her book The Cost of Counterterrorism, warned that this idea of a dichotomy - "the perilous dichotomy" - between individual liberties and security is dangerous, as it leads to a belief that every time the State believes its safety to be threatened, it is entitled to limit or restrict certain rights of its citizens. The political, social and economic costs of some measures can be excessively high, posing the question: can the cure be worse than the disease itself? Donohue (2008) also warns of the danger that temporary, exceptional measures may become permanent. The challenge to democracies is how to find a balance between security and individual liberties, without which it is the State and its values that suffers.

The aim of the present article, which is based on a survey undertaken in an international airport, is to evaluate the level of tolerance of passengers in relation to stricter security procedures at Brazilian airports, especially during major events, as well as evaluating the perceived risk of a terrorist attack during the events. The intention is to show that, although the perceived risk of a terrorist attack among the public may be low, the great majority of passengers are in favor of increased airport security during such events. In doing so it is hoped that support may be provided for the difficult task of making decisions based on complex factors such as costs, risks and potential benefits. 
While not intending to suggest what measures or procedures should be implemented, this article argues that brazilian airport security bodies can and should, within their financial reality, aim to increase security procedures in airports during major events. However, taking into consideration the low risk perception demonstrated by passengers, it is likely that implementing much more rigorous procedures lacks popular legitimacy and even proportionality, as the "expert" opinion of analysts relates to the specific risks of attacks commonly associated with major events. In a country where the most basic needs of the population are not met, and where, in terms of security, citizens are surrounded by endemic violence in their daily lives, to provide first world standard airport security to a small minority of the population seems like a luxury. Probably, only the aforementioned violence in the streets can indirectly explain why a passenger who believes the possibility of terrorism in Brazil to be low is so willing to sacrifice his individual liberties.

\section{Theories of Risk Perception and Cost-Benefit ANALYSIS}

The making of decisions related to security policies is based on a process of risk analysis, as security measures are planned to reduce the risk of the protected legal interest or property of the State under attack, whether it is the life of a citizen or public or private property. Risk analysis of a terrorist attack is, normally, left to experts, but the decision to implement a certain security measure or not is, intrinsically, a political decision, which should undergo an evaluation not just of risks, but also of possible benefits and costs (economic, social and political).

Clinton M. Jenkin (2006) clearly described the importance of empirical studies of the risk perception of the population, as this provides a vision of how this information can - and should - form part of the decision making process. This is because the concept of risk is essentially psychological. While the concept of danger is, in a certain form, scientific and objective, risk is a socially constructed idea. Jenkin explains that, in itself, keeping people safe is not enough. They must also feel safe.

An example closer to home. A few days ago, in the city of Belo Horizonte, Minas Gerais, an unsubstantiated rumor spread across social 
networks. One of the city's most important avenues, which runs alongside one of the biggest favelas in the city, was being subjected to waves of violent muggings during the day, with guns being pointed at the heads of motorists. The news spread across Twitter, Facebook, and Whatsapp, and the result was widespread panic throughout the region, resulting in traffic jams along a number of alternative routes and a deluge of phone calls to the police, requesting assistance even though in truth nothing was happening. The risk perception of violence in Brazil's large cities is so great, equaled only by the lack of confidence in state institutions, that a simple rumor is capable of generating panic and altering the behavior of thousands of people. Later, the authorities launched a campaign warning of the danger of spreading information obtained from unknown sources and promising to punish those responsible for the rumors ${ }^{13}$.

The previous example is also connected with another social phenomenon, known as the social amplification of risk, which argues that threats interact with social, psychological, cultural and institutional processes and as a result can heighten or reduce public response to a particular event. (KASPERSON; RENN; SLOVIC; BROWN; EMEL; GOBLE; KASPERSON; RATICK, 1988). The intensity and frequency of this phenomenon, in turn, will be influenced by the manner in which the media reports facts related to a certain theme (JENKIN, 2006). The role of the media in risk amplification already has been reasonably well documented for some harzards. (BREAKWELL, 2000). The massive expansion of internet, mass media and social network use may only add to such influence. (INTERNATIONAL TRANSPORT FORUM, 2009).

Paul Slovic (1987), a leading figure among studies of risk perception, has shown that, in contrast to experts, the layman, or in other words the population in general, bases his judgments related to risk on qualitative rather than quantitative factors. Furthermore, the relative importance of these qualitative factors varies depending on the person or the type of threat. The factors that influence the perception of risk of terrorist attacks are intrinsically different from those that involve the fear of an accident at a nuclear reactor, for example. Personal factors such as race or gender, or exposure to previous traumatic experiences, can also affect individual reactions.

13 The news related to this fact can be retrieved from http://www.em.com.br/app/noticia/ gerais/2014/02/21/interna_gerais,500534/responsaveis-por-boatos-de-violencia-na-internetpodem-ser-penalizados.html. 
Slovic (1987) and Jenkin (2006) showed that the clearest illustration of the subjective nature of risk is revealed by the discrepancies between the evaluations of risk of the layman and of experts. While analyzing a certain risk, experts base their findings strongly on estimates of mortality and probabilities, using objective data, while the risk perception of the general public is based on a variety of qualitative characteristics such as likelihood of exposure to the risk, the fear associated with the risk, and its level of unpredictability.

This discrepancy raises a debate about the isolated use of the evaluations of experts in policy decisions, especially those that involve security measures. The aim must be to find measures that both "reduce objective risk and measures that reduce perceived risk. Risk perception research can inform policy makers on how to balance objective assessments with public opinion regarding security priorities". (JENKIN, 2006, p.3). In the same way, Slovic (1987) argued for an equilibrium between expert opinion and the perception of risk of the layman.

Clearly the opposite approach has also raised problems in terms of the most efficient evaluation of a situation. It is not hard to find public policies that are unfortunately aimed solely at satisfying popular demands, based on public risk perception. More serious errors can occur when the decision making process ignores the opinion of experts.

The aforementioned Jenkin (2006) considers that a standard costbenefit analysis performed by specialists is morally insufficient to evaluate and deal with risk, being acceptable only as part of a more subjective process of evaluation (MACGREGOR; SLOVIC apud JENKIN, 2006). Meanwhile Abraham H. Wandersman and William K. Hallman (1993), in the article "Are people acting irrationally?" agree that such an analysis is insufficient for various reasons. Firstly because this type of quantitative factors used by specialists is based on presumptions that bring uncertainty to the process, secondly because the evaluator himself will have his own prejudices and influences, and thirdly because the evaluations of analysts frequently fail to consider problems and factors that are important to the public.

As such, the authors seem to suggest that security policy choices that do not take into consideration the risk perception of the population lack a certain legitimacy. What, after all is the sense of protecting a citizen from a threat from which he does not wish to be protected, or which he does not even perceive as a threat? Imagine a scenario other than public security. 
What legitimacy would a program have that obliges the citizen to undergo preventative cancer treatment, if the public believed the risk of contracting the disease to be preferable to the certainty of an unpleasant treatment that negatively affects their lives? In the case of Brazil, even though terrorism experts consider the risk of terrorist attacks during major events to be high, it is hard to argue in favor of buying state of the art airport security equipment in a country where insecurity and risk perception is much more related to daily urban violence. On the other hand, due to the unmeasurable consequences of a terrorist attack in Brazil, a balanced and proportionate security improvement, during the events, seems to be legitimate.

Making decisions based on the risk evaluation of experts and founded on cost-benefit analysis can be unreliable when the subject is terrorism, mainly because the benefits are uncertain or extremely hard to quantify, as was the conclusion reached by the International Transport Forum at the worldwide roundtable conference on Security, Risk Perception and Analysis (INTERNATIONAL TRANSPORT FORUM, 2009).

Additionally, cost benefit analysis usually functions better when dealing with situations where there is continuous criminal activity, which allows the security analyst to track the performance of measures and quickly evaluate their results. This is not the case with terrorism, as terrorist attacks are rare and their effects go much further than deaths or material damage (JENKINS, 2011) In this sense, it is worth highlighting the wealth of literature that describes the direct consequences of terrorism, particularly economic effects related to tourism, reduced foreign investment, and international trade, plus negative impacts on the stock market and economic growth. However, although there are fewer publications that aim to analyze indirect consequences such as the political and social costs of terrorism, some studies demonstrate that terrorist attacks can affect the happiness and general life satisfaction of the population (FREY; LUECHINGER; STUTZER, 2004).

Connected, to a certain degree, with this notion of the costs and benefits of security measures is the idea of trade-offs, consciously or subconsciously implicit in every security measure (SCHNEIER, 2003). According to some security analysts, it is difficult to imagine security measures that do not imply the limitation or restriction of some kind of individual freedom. As such, the best question is not "is this measure effective?" Instead it is far better to question if the relevant measure represents a good trade-off (SCHNEIER, 2008). These trade-offs are subjective and different people (depending on ethnic group, color, social 
class and other factors) tend to interpret the consequences of the measures in different ways. The importance given by each person to the different rights or legal assets at stake is clearly different.

In terms of airports, security procedures have become progressively more uncomfortable for passengersfollowing September 11 th, and discussions about the best way to avoid an attack appear endless. Every time there is an attempted attack on an airport or plane, new procedures are introduced in an attempt to avoid the same "modus operandi" being repeated. In this sense, the terrorism expert Brian Jenkins has made some interesting observations, which illustrate the complexity of the aforementioned concept of trade-offs and cost-benefit analysis in terms of terrorism and airport security:

Critics accuse airline security of being reactive and of responding to the last attack. They are right, but this is true of virtually all security. It is easy to conjure up new terrorist scenarios for which security measures are not currently in place - everyone has a little armchair terrorist inside them - but it is difficult to obtain funding or public acquiescence to security measures to protect against things that have not happened. Without the shoe bomber, can one imagine passengers being required to remove their shoes? Could restricting carry-on liquids have been done before the discovery in 2006 of a terrorist plot involving liquid explosives? Yet once an event occurs, it is difficult to argue against adopting new measures to prevent its repetition.

A response to the question of whether Brazil should increase security measures at its airports, including using more invasive procedures, on an extraordinary and temporary basis during the major events the country will host, seems to lead in two opposite directions when the results of the two main themes of the survey are studied. If, on the one hand, low risk perception leads to the inference that tighter airport security procedures would have little legitimacy, contrastingly the high tolerance of passengers in relation to this possibility suggests the potential benefits outweigh the costs.

\section{Method, Results and Discussion}

The survey was performed between December $24^{\text {th }} 2013$ and February $22^{\text {nd }} 2014$, in the international departures lounge of Aeroporto Internacional Tancredo Neves, located in the metropolitan area of the city of Belo Horizonte in the state of Minas Gerais. More than ten million 
people use the airport every year, making it the $5^{\text {th }}$ busiest airport in Brazil ${ }^{14}$. The passengers responded to printed questionnaires, after passing through security and immigration (Federal Police) checks, in the international departures area. The questionnaires were available in English, Portuguese and Spanish, which are shown in appendices A, B and C, with the aim of comparing the opinions of Brazilians and foreign travelers using the airport. Once approached, passengers who were interested in participating in the survey were informed that the aims of the study were purely academic, and that there was no connection with public bodies or with the adoption of future airport security policies.

The aim of the survey was to study two main aspects related to terrorism: the perception of risk of a terrorist attack during the two major events that Brazil will soon host, and the level of tolerance of passengers in relation to potential security procedures implemented in airports during such events. The survey was based on the following hypotheses: 1) Brazilians, or at least, those who make use of commercial aviation have a low perception of risk of terrorism; 2) this population group would have a low level of tolerance towards a potential increase in security procedures, even if implemented on an exceptional and temporary basis during the events. The first one was confirmed, while the second was not.

However, some observations should be made in relation to the quantitative and qualitative aspects of the sample. Initially, it should be stressed that the sample was relatively small, comprising 147 questionnaires completed by Brazilians and 43 by foreign passengers. Additionally, while data relating to monthly family income was not collected, analysis of educational level and the frequency with which passengers reported travelling abroad revealed a sample group that was quite different from what might be considered "the average Brazilian". As a result care is required in the analysis of the conclusions of the study. While the sample is not representative of the "Brazilian people", however, it can be considered to represent the part of the Brazilian population that frequents airports ${ }^{15}$. Additionally, within this context, it is possible that different results would be obtained from a survey undertaken in the domestic departures lounge.

14 Retrieved from http://en.wikipedia.org/wiki/Tancredo_Neves_International_Airport.

15 Furthermore, even though the sample does not represent the "average brazilian", it could be argued that the results are somehow relevant, since the sample may best represent the future "potential" population that could afford the tickets for a World Cup or Olympics, and therefore become a target. 
Statistics referring to the personal data of the Brazilian passengers, such as gender, age, educational level and frequency of foreign air travel are found in appendices D, E, F and G.

Risk perception in relation to terrorism was evaluated both in terms of commercial aviation and more general terrorist attacks during major sporting events. The results can be seen in the graphs contained in appendices H, I, J. When asked if they felt safe when travelling by plane in Brazil, 90\% of Brazilian passengers said yes, as displayed in the graph (appendix H). A percentage of $85 \%$ answered "the same" in relation to the feeling of safety when flying in other countries. This difference is insignificant when the percentage of people that did not have an opinion about their feeling of safety when flying in other countries is considered.

Analyzing answers to the question "What kind of concerns/fears do you have while travelling by plane in Brazil?" the following results were obtained:

\begin{tabular}{|c|c|c|}
\hline Answer Options & $\begin{array}{c}\text { Response } \\
\text { Percent }\end{array}$ & $\begin{array}{c}\text { Response } \\
\text { Count }\end{array}$ \\
\hline I don 't have any concerns or fears & $37.0 \%$ & 54 \\
\hline Mechanical problems & $37.7 \%$ & 55 \\
\hline Human error & $35.6 \%$ & 52 \\
\hline Bad weather & $34.9 \%$ & 51 \\
\hline Criminal activities(such as hijackings or terrorism) & $6.2 \%$ & 9 \\
\hline Others (please specify) & $4.8 \%$ & 7 \\
\hline Answered Question & \multicolumn{2}{|c|}{$\mathbf{1 4 6}$} \\
\hline Skipped Question & \multicolumn{2}{|c}{} \\
\hline
\end{tabular}

Only $6.2 \%$ of participants selected the option "criminal activities (such as hijackings or terrorism)", represented by the dark blue bar in the Appendix J graph, indicating low perception of risk of a terrorist attack involving aviation.

The same low perception was noted in response to the following question: "How likely do you think a terrorist attack in Brazil is during international events such as the football World Cup and Olympics?", where $60.3 \%$ of people considered the risk low or very low, as shown in the graphs below and appendix K. In this case, the question was not specifically related to aviation, but to risks specific to major events: 


\begin{tabular}{|c|c|c|}
\hline $\begin{array}{c}\text { How likely do you think a terrorist attack in Brazil is during international events such } \\
\text { as the football World Cup and Olympics?? }\end{array}$ \\
\hline Answer Options & $\begin{array}{c}\text { Response } \\
\text { Percent }\end{array}$ & $\begin{array}{c}\text { Respon- } \\
\text { se Count }\end{array}$ \\
\hline very low & $14.4 \%$ & 21 \\
\hline Low & $45.9 \%$ & 67 \\
\hline Medium & $29.5 \%$ & 43 \\
\hline High & $8.9 \%$ & 13 \\
\hline very high & $1.4 \%$ & 2 \\
\hline Answered Question & \multicolumn{2}{|c|}{$\mathbf{1 4 6}$} \\
\hline Skipped Question & \multicolumn{2}{|c|}{} \\
\hline
\end{tabular}

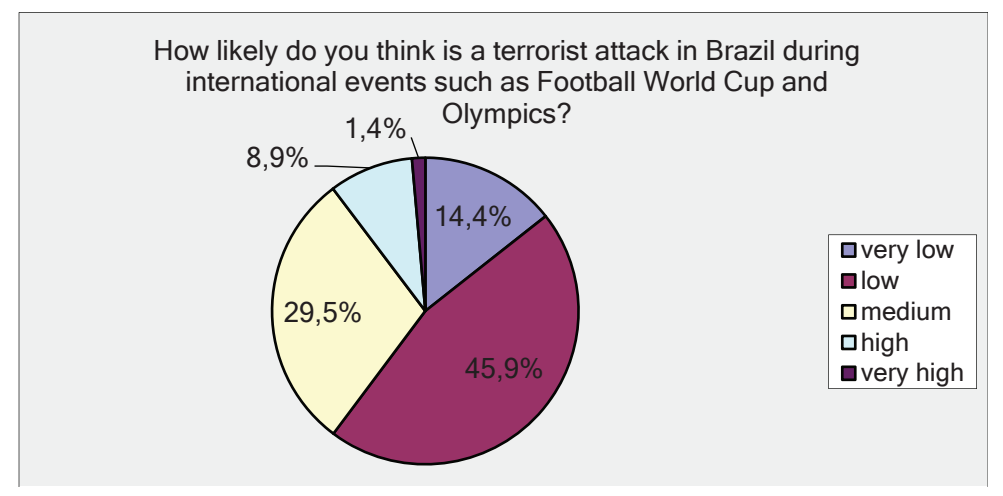

As the studies by Jenkin (2006) and Slovic (1987) have showed, a range of factors affect the formation of the risk perception of a society, and more thorough studies, specifically related to this theme, are necessary in order to identify these elements. Among factors previously cited in literature, which can also affect the phenomenon of amplification or reduction of risk, perhaps one or two are of particular relevance to Brazil, such as, for example, does the attack represent a new threat to society ("novelty"). However, as has been stated, the size and the specific nature of the sample makes it difficult to extend the results to make general observations about Brazilian society as a whole, especially when the heterogeneous nature of the population of the country is considered.

Also in terms of risk perception, the results revealed other findings of interest which will perhaps be surprising to some readers. While the majority had low or very low risk perception, around $38.35 \%$ of passengers considered the risk of a terrorist attack during the events to be medium or 
above. Additionally, analyzing the responses in terms of age range (appendix L), it was noted that this percentage rose to $47.20 \%$ among those aged between 18 and 30 years. In other words, practically half the young people in this age range considered the risk to be medium, high or very high.

The reasons why this age range has a relatively high perception of risk requires more thorough investigation. However, existing studies have provided some clues. One of these is the relationship that this age range has with the internet. It is not difficult to find surveys that demonstrate that the greatest use and influence of the internet is among young people in this age range, especially in terms of social networks ${ }^{16}$, tendencies that continue to increase. To some extent, young people appear to be more exposed to the media which in itself has a considerable role to play in determining risk perception (WOODS; EYCK; KAPLOWITZ, SHLAPENTOKH, 2008). Additionally, the internet and social networks can influence how risk is communicated ${ }^{17}$, potentially affecting the so-called social amplification of risk. Perhaps, in some form, people tend to question less information shared by a peer, who forms part of their social group or Facebook "group of friends".

Another interesting finding was that risk perception was higher among women than men, a result that was also revealed by other surveys (MARSHALL; HOLLANDER apud JENKIN 2006). The relationship between age and risk perception is not clearly identifiable, as confirmed by Jenkin (2006), following the review of a number of studies with contradictory results.

The graph in appendix $\mathrm{M}$ shows risk perception among men and women. While almost $67 \%$ of men reported low or very low risk, the same percentage fell to $47 \%$ among women who were asked about the possibility of a terrorist attack during the events.

The second hypothesis, which is that Brazilians have little tolerance in relation to the possibility of increased security measures being implemented during the World Cup and the Olympics, was not confirmed by the results of the survey. This hypothesis was based on the opinions of a large number of people involved in security operations at airports in Brazi ${ }^{18}$,

16 Retrieved from http://www.pamorama.net/2010/08/31/social-media-and-older-adults/.

17 This is one of the conclusions reached at a Expert Round Table on Social Media and Risk Communication during Times of Crisis. Retrieved from http://www.boozallen.com/media/file/ Risk_Communications_Times_of_Crisis.pdf.

18 Retrieved from http://www.aeroportoguarulhos.net/noticias/aviacao/brasil-nao-tem-a-cultura-de- 
who believe that the Brazilian passenger does not have a "culture of security" and is uncomfortable even with simpler, routine procedures.

As is shown in the appendix S, half of the passengers (50\%) believe that security procedures in Brazil are less strict than those they have encountered in other countries, while $47.89 \%$ consider them to be similar. Only three people $(2.11 \%)$ felt that Brazil had stricter security procedures than those in other countries.

When asked: "Concerning airport security procedures during international events such as the football World Cup and Olympics, do you think that Brazil..." the great majority of those interviewed completed the phrase by saying that Brazil should increase its security procedures during major events (appendix T). Fewer than $9 \%$ said that such measures should be increased at least for domestic flights, and less than $16 \%$ believed that Brazil does not need to change its security measures. Even those who answered that procedures in Brazil are similar or even stricter than those in other countries, the majority would like to see these procedures increased.

When asked if they would feel uncomfortable undergoing specific procedures more rigorous than those which they are normally used to in Brazil, such as pat downs, full body scanners (backscatter x-rays) or interviews, the grand majority said that they would not object (appendix N).

In relation to the questionnaires completed by foreigners, some observations are worth noting, despite the sample being much smaller. While those interviewed in Spanish (22 of 24 interviewees were South Americans) considered Brazilian procedures to be more strict (appendix $\mathrm{O}$ ), the most of those who responded in English (the great majority of whom were from the USA) considered, like Brazilians, security procedures in the country to be less strict, and were in favor of more rigorous measures (appendix $\mathrm{Q}$ ).

In terms of risk perception, South Americans had a considerably lower perception of risk of terrorism in Brazil than Brazilians (appendix P), while 52\% of passengers from the USA (excluding passengers from other countries) said that the risk was medium or above, compared to $39.8 \%$ of Brazilians (appendix R). 
The results revealed two apparently paradoxical findings. On the one hand, the hypothesis that Brazilians, or more accurately Brazilian citizens who use commercial aviation on a regular basis, have a low perception of the risk of terrorism in Brazil. On the other hand, even passengers who do not believe greatly in the possibility of terrorist attacks, not even during major events, feel that Brazil needs to increase its airport security, and are willing to undergo more invasive security procedures. From the presupposition that security procedures exist mainly to prevent criminal activity (while accepting that many such procedures serve to avoid accidents), why should the citizen therefore be willing to have his or her rights and freedoms limited still further because of a risk that may even be considered improbable?

While this article does not intend to clarify this apparent contradiction, it is hard to imagine an answer that does not take into account the everyday urban violence that plagues Brazil.

It's likely that the airport departures lounge is one of the safest "public" spaces in Brazil. Much safer than a bank, a school, a police station or the majority of public buildings, and infinitely safer than the streets themselves. It would not be an exaggeration, then, to state that the airport is an island amidst a sea of unsafe waters. It is probable that passengers with the social profiles of those present in the international departures lounge, or in other words, citizens of the middle or upper social classes, would be willing to undergo more invasive or awkward security procedures if it meant preserving the safety and security of the airport environment.

Furthermore, even if the average perception of risk can still be considered low, it is possible that many will be surprised by the number of people that considered the risk of an attack to be medium or high. However, as previous surveys about this subject could not be found, it was difficult to conclude if this perception is genuinely increasing, or if it is a result of the wider coverage given to terrorism by the media in the light of the upcoming events, given that there appears to be a relationship between the media and the perception of risk of terrorism. One possible explanation, which is plausible for the case in question, is that technology and greater "media consumption" has made the evaluations of risk of experts more accessible, which in turn influences the layman (TVERSKY; KAHNMAN apud. WOODS; EYCK; KAPLOWITZ, SHLAPENTOKH, 2008). 


\section{Conclusion}

Airport security has changed since $9 / 11$, altering its paradigms. Instead of simply searching for bombs, the goal now is also to find the terrorist himself (ORGAD; HASISI, 2012). However, while airport security has become more efficient (JENKINS, 2006), the improvements have brought greater restrictions of individual liberties and accusations of racism and ethnic prejudice.

As such, during the creation of security policies for airports, particularly with major sporting events on the horizon, it is essential to remember that the costs and consequences of an attack go beyond the economic cost of implementing new procedures or the immediate financial damage caused by an attack. When analyzing the possible benefits and costs of security measures, not only must the perception of risk evaluated by terrorism experts be considered, but also that of the population or the public service user. As previously mentioned, it is not enough for the citizen to be safe, he or she must also feel safe.

In this sense, the survey on which this article was based supplied answers which can assist the decision maker in the measurement of the possible political costs of a potential increase in the security procedures of airports in Brazil, by indicating that the "average" Brazilian air passenger agrees with and is willing to undergo more invasive security measures, with the goal of providing greater safety. However, in contrast to the passenger's tolerance of increased security, a relatively low perception of risk was found among the majority of passengers, leading to the conclusion that largescale investment in tighter permanent, and therefore supposedly more effective, airport security, would have low levels of support and legitimacy. Therefore there is a proportionality between risk as evaluated by experts and the tolerance and perception of risk of passengers, if such measures are implemented on a temporary basis,

In a country where the basic needs of the population are not met, and with public safety comparable to countries considered to be "failed states", investments in airport security of first world standards seems to be a forbidden luxury. 


\title{
5. ACKNOWLEDgEMENTS
}

I would like to thank my anonymous reviewers who contributed to this article. This paper was written as an evaluation of the subject "Key Concepts and Case Studies in Contemporary Terrorism", part of the International Relations' Masters at PUC Minas and given by invited professor PhD Rashmi Singh.

\section{Segurança de Aeroportos, Terrorismo e MEGAEVENTOS: ATÉ ONDE PODEMOS E DEVEMOS IR?}

\begin{abstract}
RESUMO
O 11 de setembro lembrou ao mundo de algo que parecia estar esquecido: a importância da aviação comercial como alvo terrorista. Não há dúvidas que, durante os últimos 50 anos, a aviação comercial tem sido um dos alvos favoritos de terroristas, fato que tem feito dos aeroportos um foco crucial de medidas políticas antiterroristas. Com o Brasil recebendo dois dos maiores eventos esportivos do mundo, a Copa do Mundo e as Olimpíadas, os olhos do mundo estão focados na preparação da segurança do país para tais eventos. Talvez, pela primeira vez, os órgãos responsáveis pela segurança pública necessitem levar mais seriamente o tema terrorismo em consideração no planejamento da segurança nacional, com desafios consideráveis pela frente. Os recentes protestos populares nas ruas, muitos dos quais terminaram em violência, conflitos no Oriente Médio, crises econômicas e falta de confiança da população no governo são fatores de risco que aumentam as dificuldades. Um potencial aumento das medidas de segurança nos aeroportos não somente representa um custo financeiro, mas também implica maiores constrangimentos e limitações de direitos e liberdades individuais, que, por sua vez, podem representar um custo político para o governo. Encontrar um equilíbrio entre custos, riscos e possíveis benefícios é a chave para a escolha de medidas que sejam necessárias, implementáveis e adequadas para determinados contextos políticos, econômicos e sociais. $\mathrm{O}$ objetivo do presente trabalho, o qual foi baseado numa pesquisa (survey) realizada no Aeroporto Internacional Tancredo Neves (Confins/MG), é avaliar o nível de tolerância dos passageiros em relação a medidas mais rígidas nos aeroportos brasileiros, especialmente durante mega eventos, assim como medir a percepção de risco de um ataque terrorista, durante os eventos, sentida pela população. A intenção é mostrar que, ainda que a percepção do risco de um ataque seja baixo, paradoxalmente,
\end{abstract}


a grande maioria dos passageiros apoiam um incremento das medidas de segurança nos aeroportos. Espera-se, portanto, que o presente estudo seja um suporte para as difíceis tomadas de decisões que envolvem fatores tais como riscos, custos e possíveis benefícios.

Palavras-Chave: Segurança Aeroportuária. Terrorismo. Mega Eventos. Percepção de Risco. CustoBenefício. Tomada de Decisão.

\section{Seguridad Aeroportuaria, Terrorismo Y Eventos Mega: ¿HAsta dónde PODEMOS Y DEBEMOS IR?}

\section{RESUMEN}

El 11 de septiembre le recordó al mundo de algo que parecía olvidado: la importancia de la aviación comercial como un objetivo terrorista. No hay duda de que durante los últimos 50 años, la aviación comercial ha sido uno de los objetivos favorito de los terroristas, un hecho que ha convertido a los aeropuertos un enfoque crucial de las medidas antiterroristas. Con Brasil recibiendo dos de los mayores eventos deportivos del mundo, la Copa Mundial y los Juegos Olímpicos, los ojos del mundo se centran en la preparación para la seguridad del país para este tipo de eventos. Tal vez, por primera vez, los organismos responsables de la seguridad pública tengan que tomar más en serio la cuestión del terrorismo en la planificación de la seguridad nacional, con considerables desafíos para frente. Las recientes protestas en las calles, muchos de los cuales terminaron en la violencia, los conflictos en el Medio Oriente, las crisis económicas y la falta de confianza en el gobierno son factores de riesgo que aumentan las dificultades. Un posible aumento de las medidas de seguridad en los aeropuertos no solamente representa un costo financiero, sino que también implica importantes restricciones y limitaciones de los derechos y libertades individuales, que, a su vez, puede representar un costo político para el gobierno. Encontrar un equilibrio entre los costos, riesgos y posibles beneficios es la clave para la elección de las medidas necesarias, realizables y apropiadas para ciertos contextos políticos, económicos y sociales. El propósito de este estudio, que se basó en una encuesta (encuesta) que tuvo lugar en el Aeropuerto Internacional Tancredo Neves (Confins / MG), es evaluar el nivel de tolerancia de pasajeros con respecto a las medidas más restrictas en los aeropuertos brasileños, especialmente durante megaeventos, así como medir la percepción del riesgo de un ataque terrorista durante los eventos, sentidas por la población. La intención es mostrar que, aunque la percepción del riesgo de un ataque sea baja, paradójicamente, la gran mayoría de los pasajeros apoyan un aumento de las medidas de seguridad en los aeropuertos. Se espera, por tanto, que este estudio sea un apoyo para la toma de decisiones difíciles que involucra factores como los riesgos, costos y beneficios potenciales.

Palabras Clave: Seguridad Aeroportuaria. Terrorismo. Mega Eventos. La percepción del riesgo. Coste-Beneficio. La toma de decisiones. 


\section{REFERENCES}

BREAKWELL, Glynis M. Social Communication: Factors Affecting Impact. British Medical Bulletin.Vol.56, No.01(2000),p.110-120. Retrieved from <http://bmb.oxfordjournals.org/content/56/1/110. full.pdf + html $>$. Acessed on 02 mar. 2014.

DONOHUE, Laura. The Cost of Counterterrorism.Cambridge: Cambridge University Press, 2008.

ELIAS, Bartholomeu. Airport and Aviation Security. Boca Raton:Auerbach Publications, 2010.

FREY, Bruno S.; LUECHINGER, Simon; STUTZER, Alois. Calculating Tragedy: Assessing the Costs of Terrorism. CESifo Working Papers No.1341. Available at <http://www.econstor. eu/bitstream/10419/18705/1/cesifo1_wp1341.pdf >. Acessed 29 jan. 2014.

GIBBS, Jack. Conceptualization of Terrorism. American Sociological Review. Vol.54, No.3(jun.,1989), p.329-340. Available at: <http:// www.jstor.org/discover/10.2307/2095609?uid=3737664\&uid=2\& uid $=4 \&$ sid $=21102522613743>$. Acessed on 25 Feb. 2014

HOFFMAN, Bruce. Inside Terrorism. New York:Columbia University Press, 2006.

INTERNATIONAL TRANSPORT FORUM. Expert Round Table on Social Media and Risk Communication During Times of Crisis: Strategic Challenges and Opportunities, 2009. Retrieved from $<$ http://www.boozallen.com/media/file/Risk_Communications_ Times_of_Crisis.pdf >. Acessed on 02 mar. 2014

JENKIN, Clinton M. Risk Perception and Terrorism: Applying the Psychometric Paradigm. Homeland security Affairs, Vol II, No 2(July 2006). Available at $<$ http://www.hsaj.org/ ?article $=2.2 .6>$. Acessed 01 mar. 2014.

JENKINS, Brian M. Is It Time to Consider a New Approach to Airline Security. The Ripon Forum. Volume 45, No. 3, Summer 2011. Retrieved from <http://www.riponsociety.org/forum113bmj.htm> Acessed on 02 mar. 2014.

KASPERSON, Roger E.; RENN, Ortwin; SLOVIC, Paul; BROWN, 
Halina; EMEL, Jache; GOBLE, Robert; KAPERSON, Jeanne X.; RATICK, Samuel. The Social Amplification of Risk: A Conceptual Framework. Risk Analysis. Vol.8.No.2, 1988. Retrieved from <http://elib.uni-stuttgart.de/opus/volltexte/2010/5307/pdf/ ren27.pdf>. Acessed on 02 Mar 2014.

ORGAD, Liav; HASISI, Badi. War on Terror - Lessons from Israel - 1968-2008. American Law and Economics Review, Sept. 2012. Available at <http://www.juridicas.unam.mx/wccl/ ponencias/6/106.pdf> Accessed on 21 Jan. 2014.

SCHALIT, Ariel. Our view in Airport Screening. USA Today. 21 dez. 2010. http://usatoday30.usatoday.com/news/opinion/ editorials/2010-12-22-editorial22_ST_N.htm

SCHNEIER, Bruce. Beyond Fear. New York: Copernicus Books, 2003.

SCHNEIER, Bruce. On Security. Indianapolis: Wiley Publishing, 2008.

SLOVIC, Paul. Risk perception. Science, New Series, Vol. 236, No. 4799. (Apr. 17, 1987), pp. 280-285. Available at Science, New Series, Vol. 236, No. 4799. (Apr. 17, 1987), pp. 280-285

WANDERSMAN, Abraham H.; HALLMAN William K. Are People acting irrationally? American Psychologist Vol 48, No6(1993), pp.681-686. Available at <http://www.rci.rutgers.edu/ hallman/ Irrationally.pdf $>$. Acessed on 02 mar. 2014.

WILKINSON, Paul. The Challenge of International Terrorism and Its implications for the Rule of Law and Human Rights.

Commonwealth Ministers Reference Book, London, Section 1. 2007. Available at <http://www.slashdocs.com/ktnwir/ commonwealth-ministers-reference-book-2007.html >. Acessed 25 jan. 2014.

WILKINSON, Paul;JENKINS, Brian. The Aviation Terrorism And Security. London Frank Cass Publishers, 1999.

WOODS, Joshua; EYCK, Toby; KAPLOVITZ, Stan A.; SHLAPENTOKH, Vladimir. Terrorism Risk Perceptions and Proximity to Primary Terrorist Targets: How close is Too Close? Human Ecology Review. Vol.15, No 01 (2008). Retrieved from <http://www.humanecologyreview.org/pastissues/her151/ woodsetal.pdf $>$. Acessed on 04 mar. 2014. 
ZUCKERMAN, Jessica, BUCCI, Steve; CARAFANO, James J. Fifty Terror Plots.Foiled Sice 9/11. The Homegrown Threat and The Long War On Terrorism. Backgrounder.No.2682. April, 2012.

Retrieved from <http://en.wikipedia.org/w/index.php?title=List_ of_aircraft_hijackings\&action=history> . Acessed on 06 mar. 2014.

\section{APPENDICES}

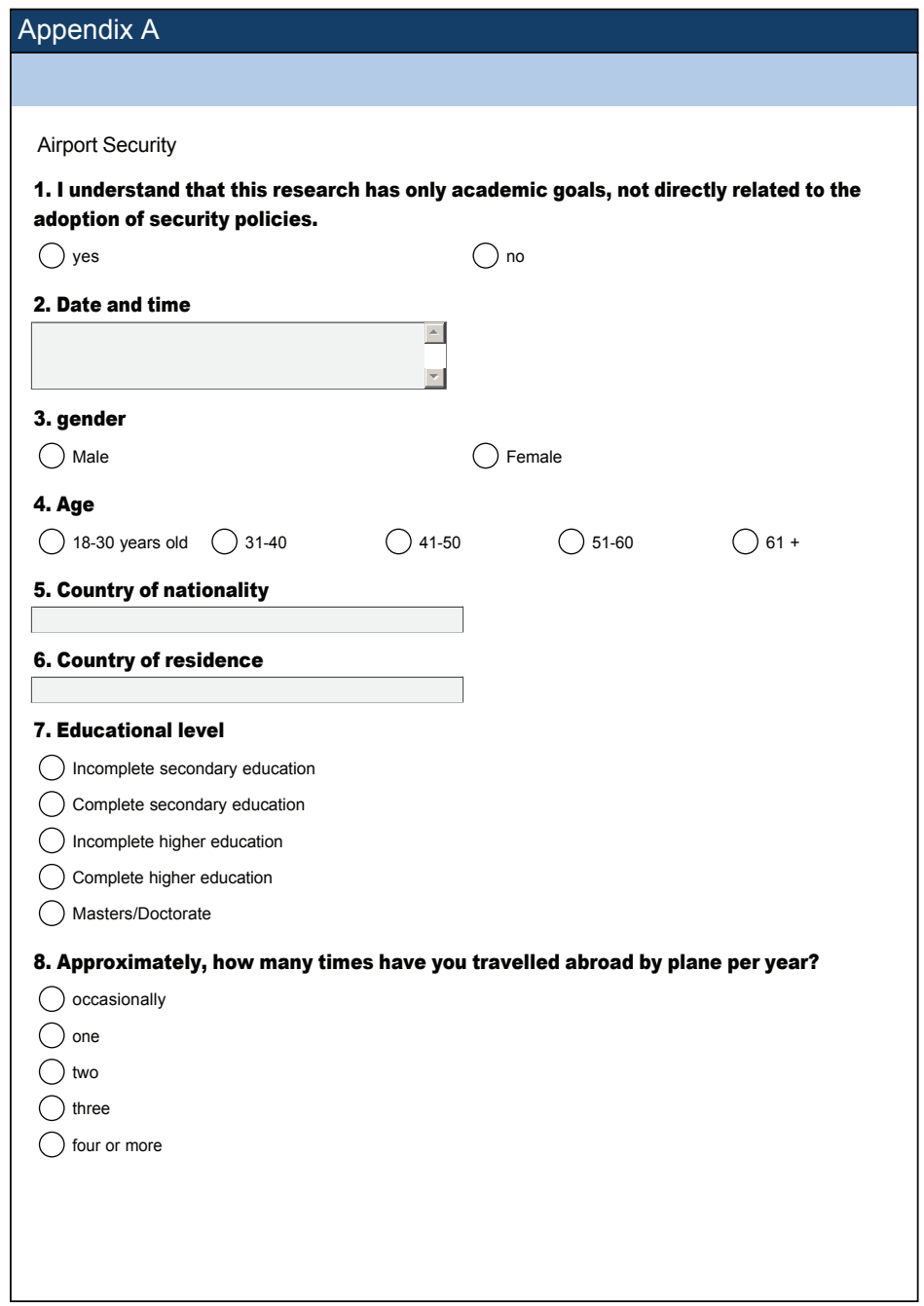




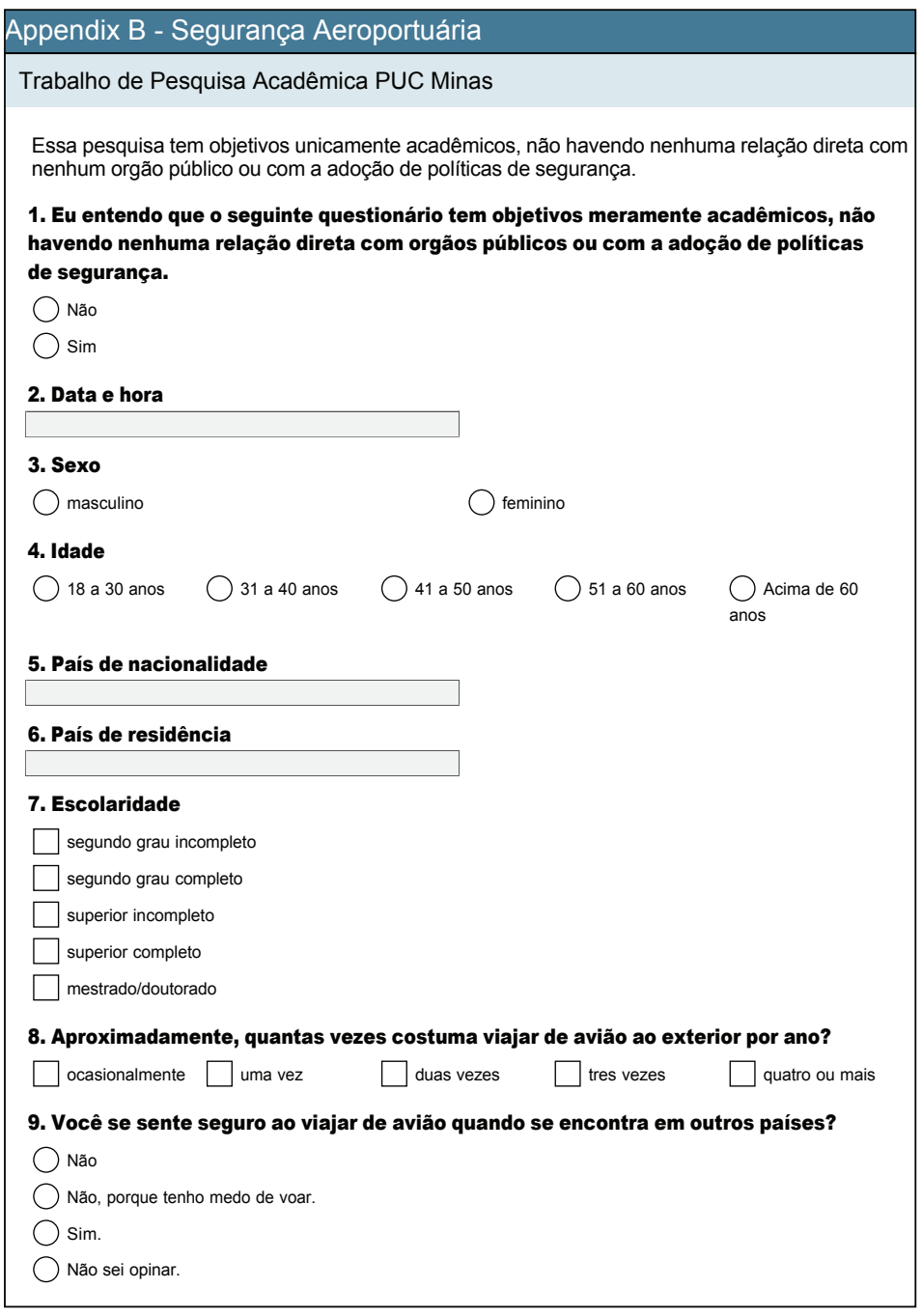


Mestrado em Relações Internacionais - Segurança Aeroportuária
10. Voc
$\mathrm{Sim}$
Não
Não, porque tenho medo de voar de avião.

11. Que tipo de preocupação ou medo você tem ao viajar de avião? (marque quantos itens desejar)

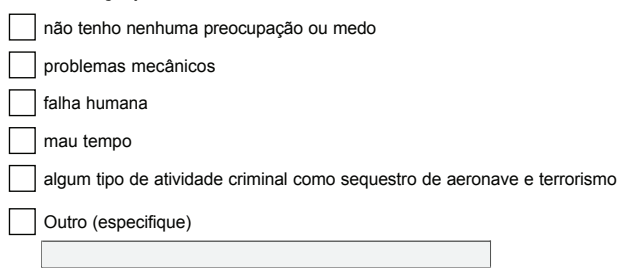

12. Em relação aos procedimentos de segurança aeroportuária, como compararia os aeroportos brasileiros com os de outros países? Você considera os procedimentos de segurança brasileiros (verificação de bagagem, raio-x etc)...
$\square$ menos rígidos
$\square$ semelhantes
mais rígidos

13. Você acredita que vai encontrar procedimentos de segurança diferenciados nos aeroportos brasileiros durante a realização dos grandes eventos que ocorrerão no país como Copa do Mundo de futebol e Olimpíadas?

$\square$ Não $\square$ Não sei opinar $\quad \square$ Acho possivel $\quad \begin{aligned} & \square \text { Tenho certeza que } \\ & \text { haverá procedimentos } \\ & \text { diferenciados }\end{aligned}$

14. Em relação aos procedimentos de segurança aeroportuários durante eventos como a Copa do mundo e Olimpíadas, você acha que o Brasil...

não necessita alterar seus procedimentos de segurança, porque os existentes são sucientes

sem opinião

deveria incrementar os procedimentos de segurança de voos domésticos

deveria incrementar os procedimentos de maneira geral, de voos domésticos e internacionais

Mestrado em Relações Internacionais - Segurança Aeroportuária

15. Por quais dos seguintes procedimentos de segurança você se sentiria incomodado de passar?

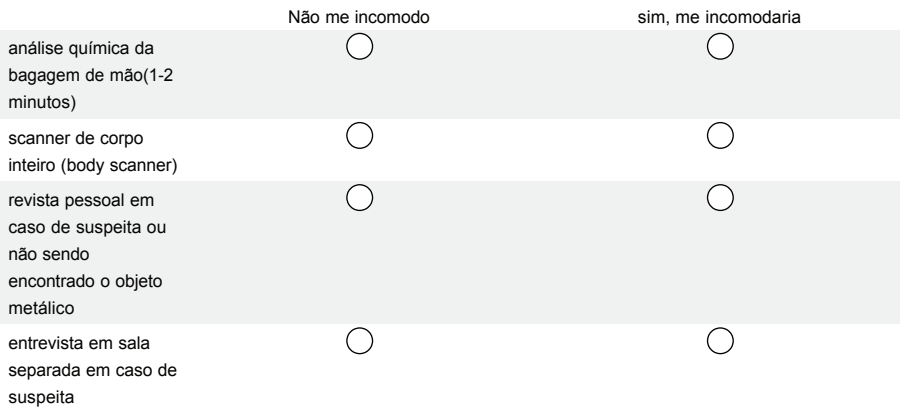

16. Como você vê a possibilidade de ocorrência de um atentado terrorista no Brasil durante eventos como a Copa do Mundo e Olimpíadas?
muito baixa
baixa
média
alta
enorme 


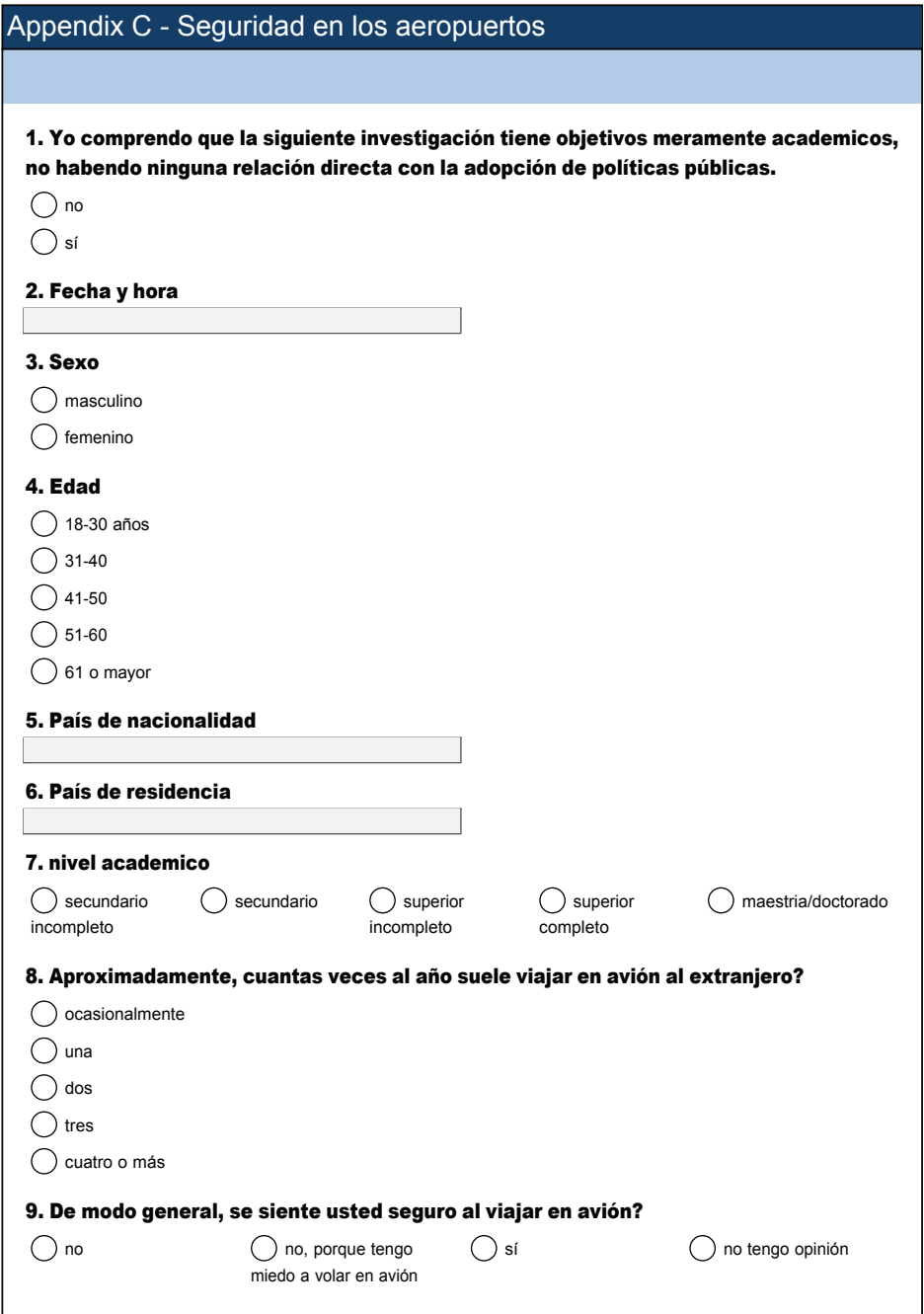




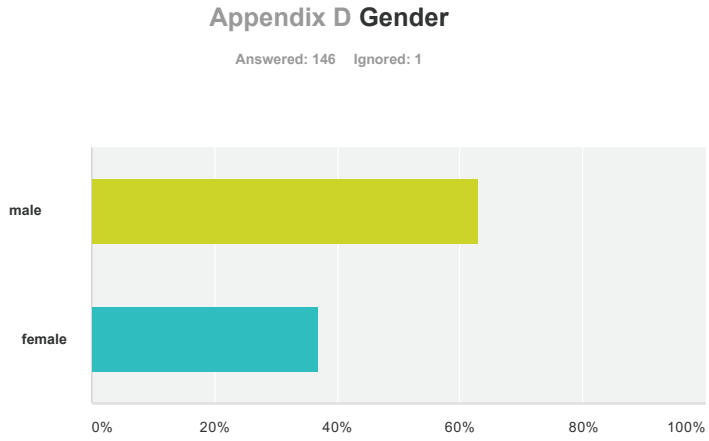

\begin{tabular}{l|lr}
\hline Options & Answers & 92 \\
\hline Male & $63,01 \%$ & 54 \\
\hline Female & $36,99 \%$ & 146 \\
\hline Total & & 140 \\
\hline
\end{tabular}

Appendix E - Age

Answered: 145 Ignored: 2

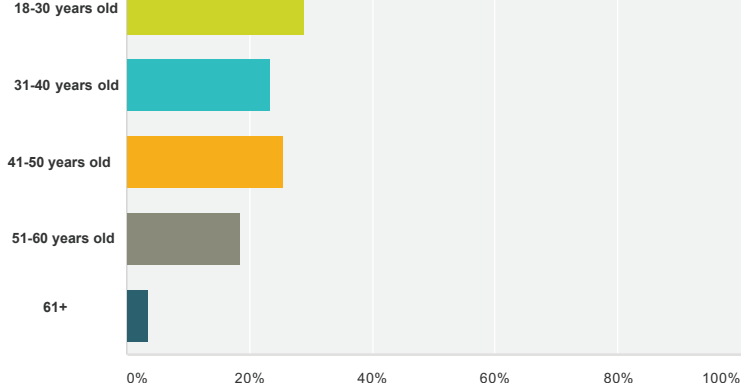

\begin{tabular}{|l|lr}
\hline Options & Answers & 42 \\
\hline $18-30$ & $\mathbf{2 8 , 9 7 \%}$ & 34 \\
\hline $31-40$ & $\mathbf{2 3 , 4 5 \%}$ & 37 \\
\hline $41-50$ & $\mathbf{2 5 , 5 2 \%}$ & 27 \\
\hline $51-60$ & $\mathbf{1 8 , 6 2 \%}$ & 5 \\
\hline $61+$ & $\mathbf{3 , 4 5 \%}$ & $\mathbf{1 4 5}$ \\
\hline Total & & \\
\hline
\end{tabular}


Airport Security, Terrorism and Mega Events: how far can and should we go?

Appendix F educational level

Answered: 147 Ignored: 0

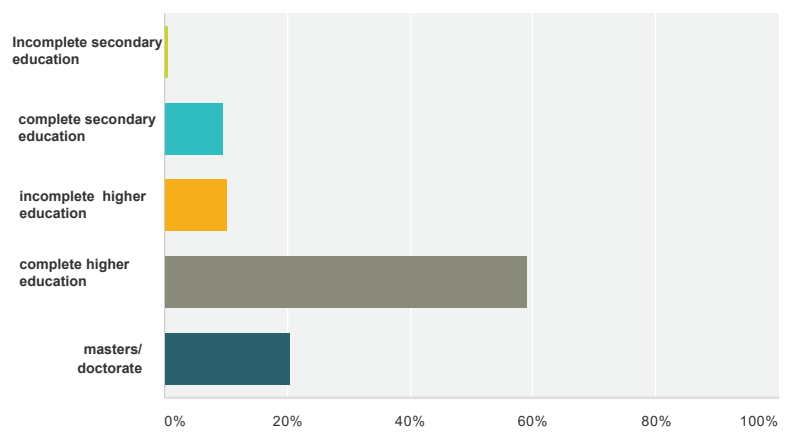

\begin{tabular}{l|lr}
\hline Options & Answered & 1 \\
\hline Incomplete second education & $\mathbf{0 , 6 8 \%}$ & 14 \\
\hline complete higher education & $\mathbf{9 , 5 2 \%}$ & 15 \\
\hline incomplete higher education & $\mathbf{1 0 , 2 0 \%}$ & 87 \\
\hline complete higher education & $\mathbf{5 9 , 1 8 \%}$ & 30 \\
\hline masters/doctorate & $\mathbf{2 0 , 4 1 \%}$ & \\
\hline Total : $\mathbf{1 4 7}$ & & \\
\hline
\end{tabular}

Appendix G - Approximately, how many

times have you travelled abroad by plane

per year?

Answered: 146 Ignored: 1

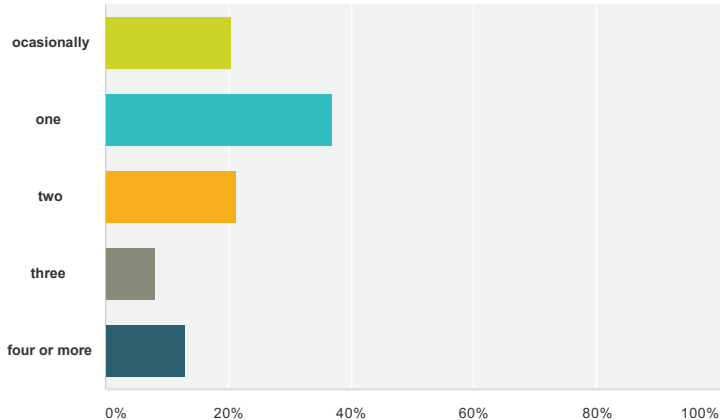

\begin{tabular}{|c|c|c|}
\hline Opçōes de resposta & Answerec & \\
\hline ocasionally & $20,55 \%$ & 30 \\
\hline one & $36,99 \%$ & 54 \\
\hline two & $21,23 \%$ & 31 \\
\hline three & $8,22 \%$ & 12 \\
\hline four or more & $13,01 \%$ & 19 \\
\hline Total : 146 & & \\
\hline
\end{tabular}




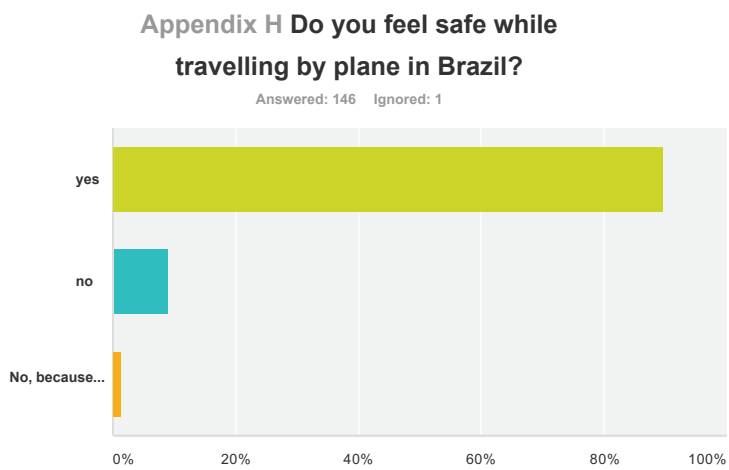

\begin{tabular}{l|lr}
\hline Options & \multicolumn{2}{|l}{ Answers } \\
\hline yes & $\mathbf{8 9 , 7 3 \%}$ & 131 \\
\hline No & $\mathbf{8 , 9 0 \%}$ & 13 \\
\hline No, because I'm afraid of flying & $\mathbf{1 , 3 7 \%}$ & 2 \\
\hline Total & & $\mathbf{1 4 6}$ \\
\hline
\end{tabular}

Appendix I Do you feel safe while travelling by plane in countries others than Brazil? Answered: 146 Ignored: 1

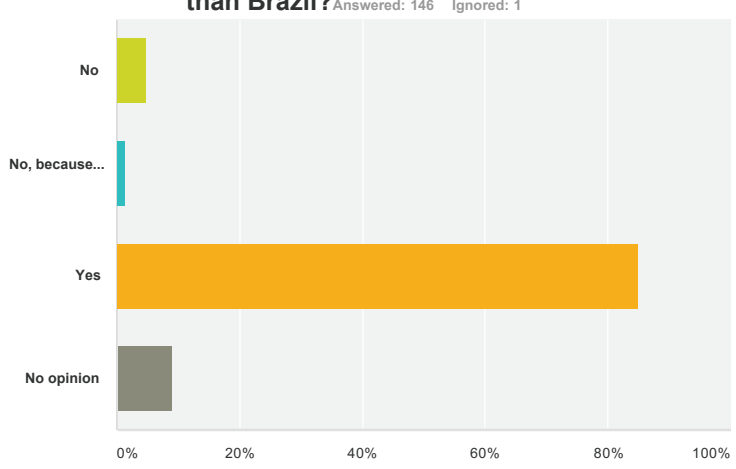

\begin{tabular}{l|lr}
\hline Options & \multicolumn{2}{|l}{ Answers } \\
\hline No & $\mathbf{4 , 7 9 \%}$ & 7 \\
\hline No, because Im afraid of flying & $\mathbf{1 , 3 7 \%}$ & 2 \\
\hline Yes & $\mathbf{8 4 , 9 3 \%}$ & 124 \\
\hline No opinion & $\mathbf{8 , 9 0 \%}$ & 13 \\
\hline Total & & $\mathbf{1 4 6}$ \\
\hline
\end{tabular}


Airport Security, Terrorism and Mega Events: how far can and should we go?

Appendix J-What kind of concerns/fears do you have while travelling by plane in Brazil?

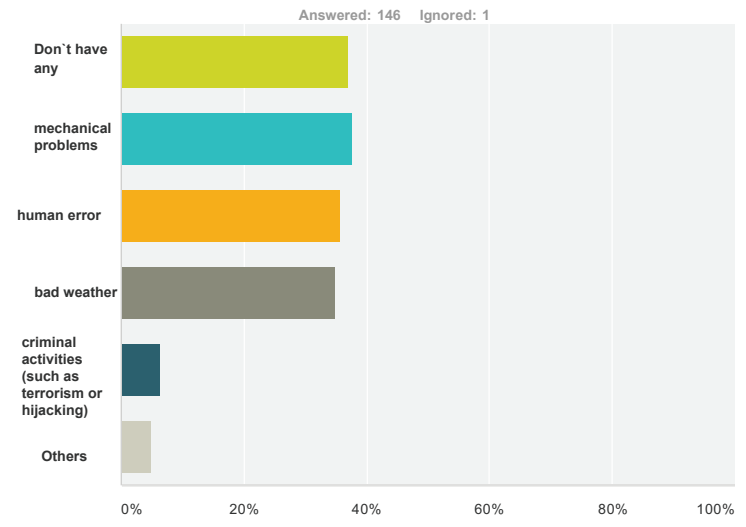

\begin{tabular}{l|lr}
\hline Opçöes de resposta & \multicolumn{2}{|l}{ Respostas } \\
\hline I don't have any concerns or fears & $36,99 \%$ & 54 \\
\hline mechanical problems & $\mathbf{3 7 , 6 7 \%}$ & 55 \\
\hline human error & $35,62 \%$ & 52 \\
\hline bad weather & $34,93 \%$ & 51 \\
\hline criminal activities (such as terrorism or hijacking) & $\mathbf{6 , 1 6 \%}$ & 9 \\
\hline Others (please specify) & $\mathbf{4 , 7 9 \%}$ & 7 \\
\hline Answers: 146 & & \\
\hline
\end{tabular}


Appendix K - How likely do you

think is a terrorist attack in Brazil

during international events such as

Football World Cup and Olympics?

Respondidas: 146 Ignoradas: 1

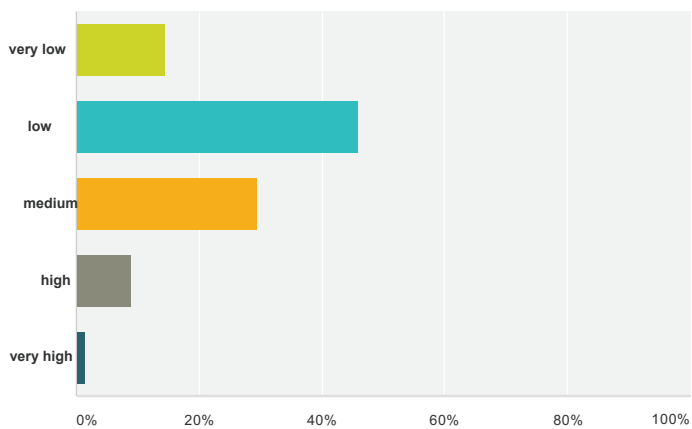

\begin{tabular}{l|lr}
\hline Answer options & Answers & 21 \\
\hline very low & $\mathbf{1 4 , 3 8 \%}$ & 67 \\
\hline low & $\mathbf{4 5 , 8 9 \%}$ & 43 \\
\hline medium & $\mathbf{2 9 , 4 5 \%}$ & 13 \\
\hline & $\mathbf{8 , 9 0 \%}$ & 2 \\
\hline very high & $\mathbf{1 , 3 7 \%}$ & $\mathbf{1 4 6}$ \\
\hline Total & & \\
\hline
\end{tabular}

Appendix L How likely do you think a

terrorist attack in Brazil is during

international events such as the football

World Cup and Olympics?

Respondidas: 144 Ignoradas: 1

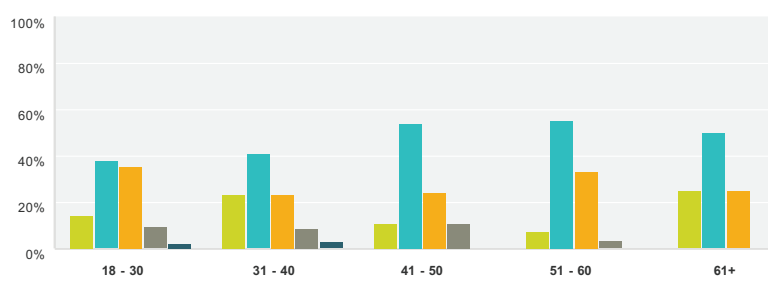

very low low medium high very high

\begin{tabular}{|c|c|c|c|c|c|c|}
\hline & very low & low & medium & high & very high & Total \\
\hline 18 - 30 years-old & $\begin{array}{r}14,29 \% \\
6\end{array}$ & $\begin{array}{r}38,10 \% \\
16\end{array}$ & $\begin{array}{r}35,71 \% \\
15\end{array}$ & $\begin{array}{r}9,52 \% \\
4\end{array}$ & $\begin{array}{r}2,38 \% \\
1\end{array}$ & 42 \\
\hline 31 - 40 years-old & $\begin{array}{r}23,53 \% \\
8\end{array}$ & $\begin{array}{r}41,18 \% \\
14\end{array}$ & $\begin{array}{r}23,53 \% \\
8\end{array}$ & $\begin{array}{r}8,82 \% \\
3\end{array}$ & $\begin{array}{r}2,94 \% \\
1\end{array}$ & 34 \\
\hline 41-a 50 years-old & $\begin{array}{r}10,81 \% \\
4\end{array}$ & $\begin{array}{r}54,05 \% \\
20\end{array}$ & $\begin{array}{r}24,32 \% \\
9\end{array}$ & $\begin{array}{r}10,81 \% \\
4\end{array}$ & $\begin{array}{r}0 \% \\
0\end{array}$ & 37 \\
\hline 51 - 60 years-old & $\begin{array}{r}7,41 \% \\
2\end{array}$ & $\begin{array}{r}\mathbf{5 5 , 5 6 \%} \\
15\end{array}$ & $\begin{array}{r}33,33 \% \\
9\end{array}$ & $\begin{array}{r}3,70 \% \\
1\end{array}$ & $\begin{array}{r}0 \% \\
0\end{array}$ & 27 \\
\hline $61+$ & $\begin{array}{r}\mathbf{2 5} \% \\
1\end{array}$ & $\begin{array}{r}50 \% \\
2\end{array}$ & $\begin{array}{r}\mathbf{2 5} \% \\
1\end{array}$ & $\begin{array}{r}0 \% \\
0\end{array}$ & $\begin{array}{r}0 \% \\
0\end{array}$ & 4 \\
\hline Total & 21 & 67 & 42 & 12 & 2 & 144 \\
\hline
\end{tabular}


Appendix M How likely do you think is a terrorist attack in Brazil during international events such as Football World Cup and Olympics? Answered: 145 Ignored: 1

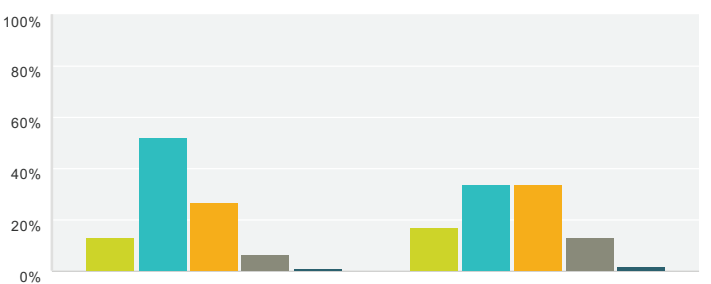

Q3: male Q3: female

very low $\square$ medium $\square^{\text {high }}$

\begin{tabular}{|c|c|c|c|c|c|c|}
\hline & very low & low & medium & high & very high & Total \\
\hline Q3: male & $\begin{array}{r}\mathbf{1 3 , 0 4 \%} \\
12\end{array}$ & $\begin{array}{r}52,17 \% \\
48\end{array}$ & $\begin{array}{r}\mathbf{2 7 , 1 7 \%} \\
25\end{array}$ & $\begin{array}{r}6,52 \% \\
6\end{array}$ & $\begin{array}{r}1,09 \% \\
1\end{array}$ & 92 \\
\hline Q3: female & $\begin{array}{r}16,98 \% \\
9\end{array}$ & $\begin{array}{r}33,96 \% \\
18\end{array}$ & $\begin{array}{r}33,96 \% \\
18\end{array}$ & $\begin{array}{r}13,21 \% \\
7\end{array}$ & $\begin{array}{r}1,89 \% \\
1\end{array}$ & 53 \\
\hline Total & 21 & 66 & 43 & 13 & 2 & 145 \\
\hline
\end{tabular}

Appendix N: I wouldn`t feel comfortable going through the following security procedures:

Answered: 146 Ignored: 1

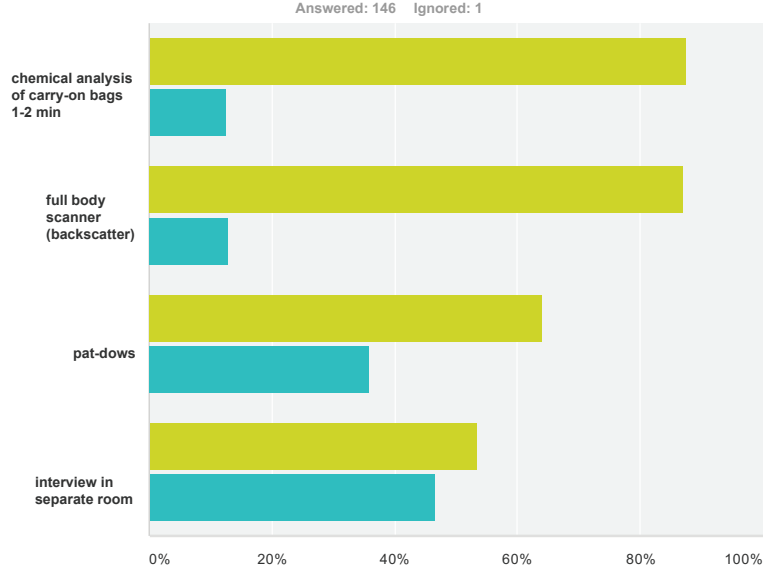

I don't mind I wouldn't feel comfortable

\begin{tabular}{|c|c|c|c|}
\hline & I don't mind & Id not feel comfortable & Total \\
\hline chemical analysis of carry-on bags (1-2 min) & $\begin{array}{r}87,50 \% \\
126\end{array}$ & $\begin{array}{r}12,50 \% \\
18\end{array}$ & 144 \\
\hline full body scanner (backscatter) & $\begin{array}{r}87,05 \% \\
121\end{array}$ & $\begin{array}{r}12,95 \% \\
18\end{array}$ & 139 \\
\hline pat down during checkpoints in case of suspicion or following a metal detection alert & $\begin{array}{r}64,14 \% \\
93\end{array}$ & $\begin{array}{r}35,86 \% \\
52\end{array}$ & 145 \\
\hline interviews in separate room in case of suspicion & $\begin{array}{r}53,52 \% \\
76\end{array}$ & $\begin{array}{r}46,48 \% \\
66\end{array}$ & 142 \\
\hline
\end{tabular}


Appendix $\mathrm{O}$ (spanish speakers) -

Concerning airport security, how would

you compare Brazilian airports with

others. Do you consider Brazilian security procedures...

Answered: 21 Ignored: 0

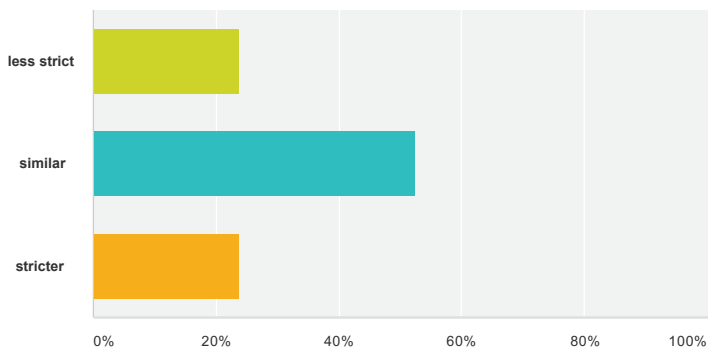

\begin{tabular}{l|lr}
\hline Options & Answers & \\
\hline less strict & $\mathbf{2 3 , 8 1 \%}$ & $\mathbf{1 1}$ \\
\hline similar & $\mathbf{5 2 , 3 8 \%}$ & 5 \\
\hline stricter & $\mathbf{2 3 , 8 1 \%}$ & $\mathbf{2 1}$
\end{tabular}

Appendix P (spanish speakers)- How likely do you think a terrorist attack in Brazil is during international events such as the football World Cup and Olympics?

Answered: 21 Ignored: 0

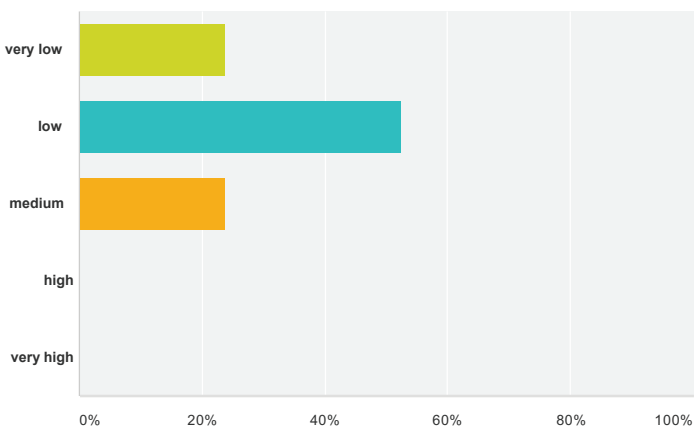

\begin{tabular}{l|lr}
\hline Options & Answers & 5 \\
\hline very low & $\mathbf{2 3 , 8 1 \%}$ & 11 \\
\hline low & $\mathbf{5 2 , 3 8 \%}$ & 5 \\
\hline medium & $\mathbf{2 3 , 8 1 \%}$ & 0 \\
\hline high & $\mathbf{0 \%}$ & 0 \\
\hline very high & $\mathbf{0 \%}$ & $\mathbf{2 1}$ \\
\hline Total & & \\
\hline
\end{tabular}


Appendix Q- Concerning airport security, how would you compare Brazilian airports with others. Do you consider Brazilian security procedures...

Answered: 22 Ignored: 0

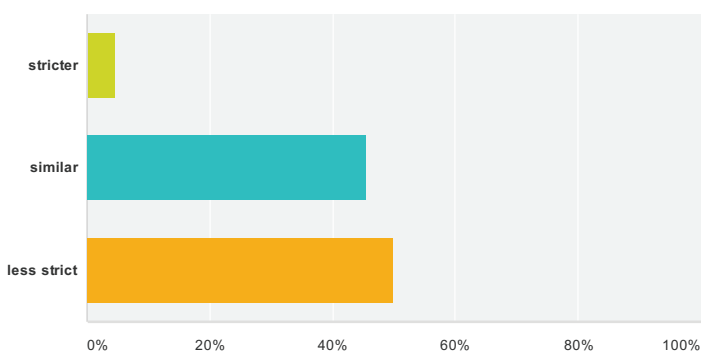

\begin{tabular}{l|lr}
\hline Options & Answers & \\
\hline stricter & $\mathbf{4 , 5 5 \%}$ & 1 \\
\hline similar & $\mathbf{4 5 , 4 5 \%}$ & 10 \\
\hline less strict & $\mathbf{5 0 \%}$ & 11 \\
\hline Total & & $\mathbf{2 2}$ \\
\hline
\end{tabular}

Appendix R (english speakers) How likely do you think is a terrorist attack in Brazil during international events such as Football World Cup and Olympics? Answered: 21 Ignored: 1

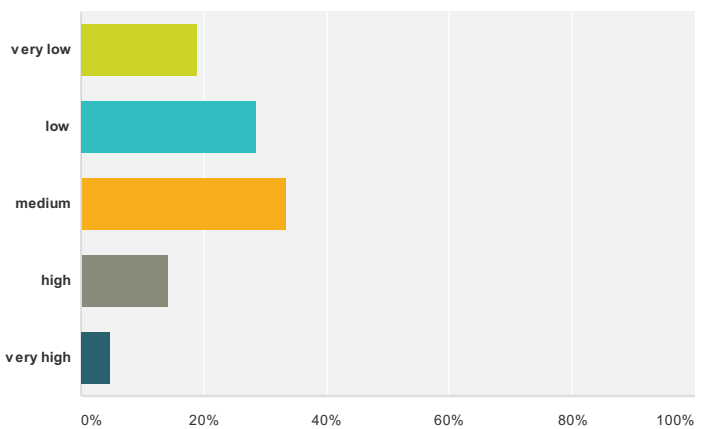

\begin{tabular}{l|lr}
\hline Options & Answers & 4 \\
\hline very low & $\mathbf{1 9 , 0 5 \%}$ & 6 \\
\hline low & $\mathbf{2 8 , 5 7 \%}$ & 7 \\
\hline medium & $\mathbf{3 3 , 3 3 \%}$ & 3 \\
\hline high & $\mathbf{1 4 , 2 9 \%}$ & 1 \\
\hline very high & $\mathbf{4 , 7 6 \%}$ & $\mathbf{2 1}$ \\
\hline Total & & \\
\hline
\end{tabular}


Appendix S Concerning airport security, how would you compare Brazilian airports with others. Do you consider Brazilian security procedures...

Answered: 142 Ignored 5

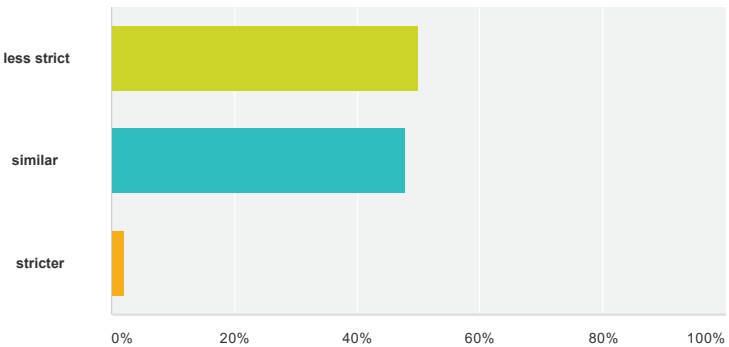

\begin{tabular}{l|lr}
\hline Options & Answers & 71 \\
\hline less strict & $\mathbf{5 0 \%}$ & 68 \\
\hline similar & $\mathbf{4 7 , 8 9 \%}$ & 3 \\
\hline stricter & $\mathbf{2 , 1 1 \%}$ & \\
\hline Total:142 & & \\
\hline
\end{tabular}

Appendix T Concerning airport security procedures during international events such as the Football World Cup and

Olympics, you think that Brazil... Answered: 90 Ignored: 57

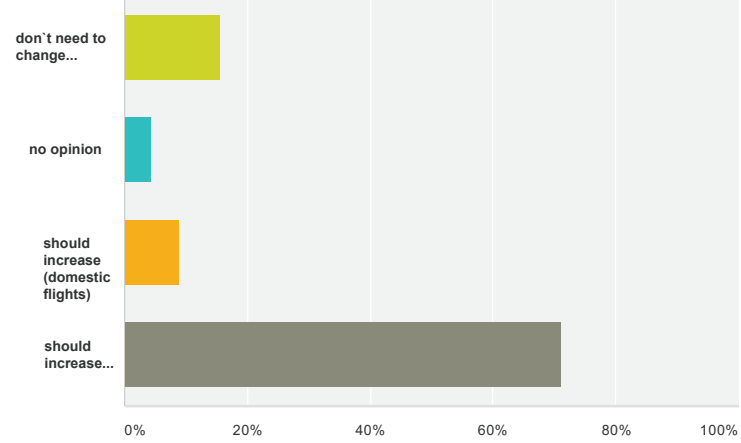

\begin{tabular}{|c|c|c|}
\hline Options & Answers & \\
\hline don't need to change its security procedures, because the existing ones are enough & $15,56 \%$ & 14 \\
\hline no opinion & $4,44 \%$ & 4 \\
\hline should increase the security procedures of domestic flights & $8,89 \%$ & 8 \\
\hline should increase the overall procedures of domestic and international flights & $71,11 \%$ & 64 \\
\hline Total & & 90 \\
\hline
\end{tabular}

